\title{
Maternally-inherited diabetes with deafness (MIDD) and hyporeninemic hypoaldosteronism
}

\author{
Diabetes mitocondrial (MIDD) e hipoaldosteronismo hiporreninêmico
}

1 Disciplina de Endocrinologia, Escola Paulista de Medicina, Universidade Federal de São Paulo (Unifesp-EPM), São Paulo, SP, Brazil
Correspondence to:

Regina S. Moisés

Universidade Federal de São Paulo

Escola Paulista de Medicina,

Disciplina de Endocrinologia

Rua Pedro de Toledo, 781, 12 anda

04039-032 - São Paulo, SP, Brazil

rmoises@unifesp.br

Received on Aug/23/2012

Accepted on Oct/26/2012
Patricia B. Mory', Marcia C. dos Santos', Claudio E. Kater', Regina S. Moisés'

\section{SUMMARY}

Maternally-inherited diabetes with deafness (MIDD) is a rare form of monogenic diabetes that results, in most cases, from an A-to-G transition at position 3243 of mitochondrial DNA (m.3243A>G) in the mitochondrial-encoded tRNA leucine (UUA/G) gene. As the name suggests, this condition is characterized by maternally-inherited diabetes and bilateral neurosensory hearing impairment. A characteristic of mitochondrial cytopathies is the progressive multisystemic involvement with the development of more symptoms during the course of the disease. We report here the case of a patient with MIDD who developed hyporeninemic hypoaldosteronism. Arq Bras Endocrinol Metab. 2012;56(8):574-7

\section{SUMÁRIO}

O diabetes mitocondrial (MIDD) é uma forma rara de diabetes monogênico resultante, na maioria dos casos, da mutação mitocondrial A3243G. Essa condição é caracterizada por diabetes de transmissão materna e disacusia neurossensorial. Uma característica das mitocondriopatias é o envolvimento progressivo de outros órgãos ou sistemas, levando ao aparecimento de diversos sintomas durante o curso da doença. Este relato descreve o caso de um paciente com MIDD que, durante o período de acompanhamento, apresentou hipoaldosteronismo hiporreninêmico. Arq Bras Endocrinol Metab. 2012;56(8):574-7

\section{INTRODUCTION}

$\mathrm{M}$ aternally inherited diabetes and deafness (MIDD) (OMIM \# 520000) is a rare form of diabetes that results, in most cases, from an A-to-G transition at position 3243 of mitochondrial DNA $(\mathrm{m} .3243 \mathrm{~A}>\mathrm{G})$ in the mitochondrial-encoded tRNA leucine (UUA/G) gene. Besides this point mutation, there are other less frequent variants also associated with MIDD (1).

MIDD is characterized, as the name suggests, by maternally-inherited diabetes and bilateral neurosensory hearing impairment. Although the age of diabetes onset is variable, many patients are young. Guillausseau and cols., in a multicenter study, found a mean age at diagnosis of diabetes of $38.8 \pm 9.6$ years, ranging from 12 to 67 years, and that the presentation is either type 1 or type 2 diabetes (2). In type 2 -like phenotype the patients can initially be treated with diet or sulphonylurea, but they may develop insulin dependency $(3,4)$. Impair- ment of insulin secretory capacity was demonstrated in individuals carrying the $\mathrm{m} .3243 \mathrm{~A}>\mathrm{G}$ mutation, possibly the primary defect contributing to the development of diabetes mellitus (5-7). The molecular mechanisms responsible for the development of this insulin-requiring diabetes are complex and seem to be related to beta-cells dysfunction, loss of beta-cells mass $(8,9)$, and insulin deficiency $(3,5-7,9)$. Possibly, the early primary defect in individuals carrying the m.3243A $>\mathrm{G}$ mutation is the impairment of insulin secretory capacity due to the progressive reduction in oxidative phosphorylation involving the glucose-sensing mechanism of beta-cells (6). The preferential replication of mtDNA molecules carrying the 3243 mutation over wild-type molecules may also be involved in the progressive loss of insulin secretion $(3,10)$.

A characteristic of mitochondrial cytopathies is the progressive multisystemic involvement, with the 
development of more symptoms during the course of the disease. Besides diabetes mellitus and deafness, the main features of MIDD, other organs may be involved. Metabolically active organs, such as muscle, retina, myocardium, cochlea, kidney, and brain are frequently affected. Myopathy is manifested as painful muscle weakness affecting the lower limbs. Muscular disorders were observed in $43 \%$ of MIDD patients (2). Macular retinal dystrophy is the most common ophthalmic abnormality, observed in $86 \%$ of patients with MIDD (11). This condition includes pigmented lesions in the retina, and atrophy of the choroid or retinal epithelium, a "salt and pepper" pigmentary retinopathy, generally without consequences on visual acuity (1). Patients with MIDD also have considerable risk for cardiac disorders. Left ventricular hypertrophy, Wolff-Parkinson-White syndrome and other cardiac conduction abnormalities, as well as heart failure have been reported in these patients $(1,12-14)$. In addition to diabetes, short stature is the most common endocrine manifestation of MIDD, and a deficiency in the release of growth hormone has been reported (15).

Coenzyme Q10 (CoQ10) plays a central role in the mitochondrial respiratory chain. It acts as an electron carrier, supporting adenosine triphosphate (ATP) synthesis in the inner mitochondrial membrane. In addition, CoQ10 has also antioxidant and membrane-stabilizing properties. Previous reports showed beneficial effects of CoQ10 on some neuromuscular symptoms, prevention of progressive insulin secretory defect, exercise intolerance, hearing loss, myocardial dysfunction, and intestinal pseudo-obstruction in MIDD patients (13,16-19).

The m.3243 A>G mutation causes an alteration of the tertiary structure of the tRNA Leu leading to abnormal dimerization of the molecule. Defects in mitochondrial protein synthesis and respiratory activity were observed in cybrid cells from patients carrying the m.3243A>G mutation (20). This mutation has also been associated with other cellular biochemical dysfunctions such as increased oxidative stress, impaired calcium homeostasis, reduced mitochondrial membrane potential, and increased apoptosis $(1,21)$.

We report here the case of a patient with MIDD who developed hyporeninemic hypoaldosteronism.

\section{CASE REPORT}

A 50-year-old man was diagnosed with diabetes mellitus at the age 19, and has been treated with insulin since then. Diabetes was diagnosed based on the history of thirst, polyuria, and body weight loss. Bilateral neurosensory hearing loss was diagnosed at the age of 28 , and required the use of a hearing aid. The patient's height and weight were $157 \mathrm{~cm}$ and $47 \mathrm{~kg}$, respectively, with a body mass index of $19.1 \mathrm{~kg} / \mathrm{m}^{2}$. Family history showed hearing loss in two sisters. The patient's mother was never diagnosed with diabetes or hearing impairment during her life; she died at the age of 78 .

Based on the findings of diabetes mellitus, hearing impairment and short stature, the patient was suspected to have MIDD. Molecular genetic analysis was then performed in the patient (proband) and available relatives. The presence of an A-to-G transition at nucleotide pair 3243 of the mitochondrial gene was identified in the proband, his two sisters, two nieces, and his mother, confirming the MIDD diagnosis. Glucose tolerance test was performed in his mother, sisters, and nieces, with normal glucose tolerance levels (Figure 1). He was started on Coenzyme Q10, 150 mg daily. Osteoporosis was also diagnosed, and alendronate $70 \mathrm{mg}$ weekly was prescribed.

In recent years, the patient's HbAlc levels have ranged from $7.1 \%$ to $8.4 \%$. Serum creatinine $(0.56$ to $0.79 \mathrm{mg} / \mathrm{dL}$ ) and albuminuria (4.6 to $7.0 \mathrm{ug} / \mathrm{min}$ in 12 hour specimen) were normal. Glomerular filtration rate was $78 \mathrm{~mL} / \mathrm{min} / 1.73 \mathrm{~m}^{2}$. Ophthalmological examination revealed ocular fundus without diabetic retinopathy.

During routine electrolyte measurements, persistent hyperkalaemia was noted with serum potassium concentrations ranging from 5.0 to $6.4 \mathrm{mmol} / \mathrm{L}$, and serum sodium ranging from 134 to $139 \mathrm{mmol} / \mathrm{L}$. Further investigation showed 24-h urinary potassium of 46

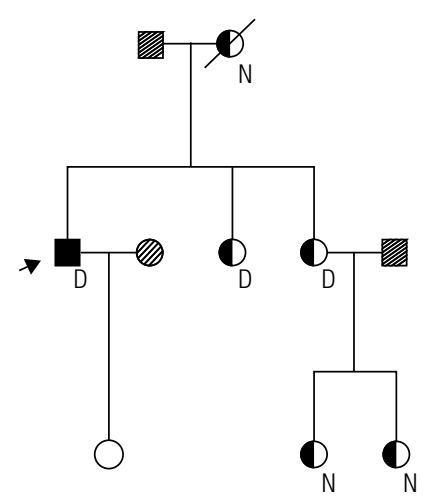

Figure 1. Pedigree of the studied family with the mitochondrial A3243G mutation. Mutation with diabetes $(\boldsymbol{\square})$, mutation with normal glucose tolerance $(\mathbf{D})$, wild gene $(\mathrm{O})$, untested (W: indicates neurosensory deafness; N: normal audiometric test. 
$\mathrm{mEq}$, urinary sodium of $362 \mathrm{mEq}$, venous $\mathrm{pH}$ of 7.32 , $\mathrm{pCO}_{2}$ of $53 \mathrm{mmHg}$, and base excess of $0 \mathrm{mmol} / \mathrm{L}$. The patient was not taking any medication other than insulin, coenzyme Q10, and alendronate. Evaluation of his renin-angiotensin-aldosterone system showed undetectable basal plasma renin activity $(<0.4 \mathrm{ng} / \mathrm{mL} / \mathrm{h}$; reference: $0.4-0.7 \mathrm{ng} / \mathrm{mL} / \mathrm{h}$ ) and serum aldosterone (basal: $<2.0 \mathrm{ng} / \mathrm{dL}$; post-ACTH: $<2.0 \mathrm{ng} / \mathrm{dL}$; reference: $2.0-16.0 \mathrm{ng} / \mathrm{dL}$ ).

Morning basal and ACTH-stimulated cortisol levels were $15.9 \mathrm{ug} / \mathrm{dL}$ (reference: $5.4-25 \mathrm{ug} / \mathrm{dL}$ ) and 27.5 ug/dL (reference: > $20 \mathrm{ug} / \mathrm{dL}$ ), respectively. These laboratory findings pointed toward hyporeninemic hypoaldosteronism. Accordingly, replacement mineralocorticoid therapy with fludrocortisone $(0.2 \mathrm{mg}$ PO daily) was instituted; one month later, he reported clinical improvement with increased strength and sense of wellbeing; his serum potassium decreased to $5.0 \mathrm{mmol} / \mathrm{L}$, and serum sodium increased to $141 \mathrm{mmol} / \mathrm{L}$.

\section{Molecular analysis of the A3243G mutation}

Total DNA was extracted from peripheral blood leukocytes using a commercial kit (Puregene DNA Isolation Kit, Gentra System, Minneapolis, MN, USA). Detection of the 3243 A-to- $G$ transition in the mitochondrial tRNA Leu (UUR) gene was carried out by polymerase chain reaction A3243G (PCR), Apa I digestion, and acrylamide gel electrophoresis. Bands were visualized by ethidium bromide staining.

\section{DISCUSSION}

In this paper, we present the case of a male patient with MIDD due to an A-to-G transition at position 3243 in the mitochondrial-encoded tRNA leucine (UUA/G) gene. The patient also developed hyporeninemic hypoaldosteronism.

Hyperkalemia occurs in diabetic patients at higher percentages than in the general population. Jarman and Mather found serum potassium $>5.0 \mathrm{mmol} / \mathrm{L}$ in $15 \%$ patients attending a diabetic clinic (22). The major causes of hyperkalemia are advanced renal failure, heart failure resulting in renal hypoperfusion, or hypoaldosteronism. Among the causes of hypoaldosteronism, the use of drugs that interfere with the release or action of aldosterone, such as non-steroidal antiinflammatory drugs, angiotensin-converting enzyme inhibitors and/or angiotensin II-receptor blockers, heparin, trimethoprim, and potassium-sparing diuretics, should all be considered. Other less frequent causes are primary adrenal insufficiency and hyporeninemic hypoaldosteronism syndrome (HHS).

Renin is produced by the juxtaglomerular cells of the kidney that are spread throughout the renal cortex. Impaired renal secretion of renin causes a deficiency in aldosterone secretion, i.e., hyporeninemic hypoaldosteronism. This disorder results in chronic natriuresis secondary to sodium loss in the distal nephron, with consequent decrease in potassium and hydrogen secretion. Retention of these ions leads to hyperkalemia and mild hyperchloremic metabolic acidosis $(23,24)$.

Reduced secretion of renin in diabetic patients may be due to several causes: small vessel kidney disease, production of an inactive form of renin, inadequate sympathetic stimulation of renin-producing cells by autonomic neuropathy, and a physiological suppression of renin release by volume overload (25-27).

Mitochondrial gene mutations underlie a number of disorders. Several tissues become functionally defective when the amount of mutant DNA exceeds a certain threshold, which depends on the mutation and the extent to which the cell relies on mitochondrial function. The presentation of $\mathrm{mt} A>\mathrm{G} 3243$ mutation is variable, ranging from mild to severe phenotypes.

The patient described here, besides mitochondrial diabetes, presented clinically manifested hyporeninemic hypoaldosteronism during the follow-up. Given that he was not taking any drug that could potentially interfere with the release or action of aldosterone and had no features of renal failure, the presence of hyperkalemia may be attributed to hyporeninemic hypoaldosteronism. Furthermore, because hyperglycemia induces the release of potassium from the intra- to the extracellular compartment, it contributes to the worsening of hyperkalemia (28). In fact, in this patient, hyperkalemia was aggravated whenever his blood glucose concentration rose (data not shown). Fludrocortisone was given to the patient, and hyperkalemia was promptly corrected.

Shimizu and cols. have previously described three familial cases of mitochondrial diabetes with hyperkalemia (29). Mild acidosis was detected and plasma renin and aldosterone concentrations were low. Histopathological examination of the kidney revealed tubulointerstitial changes and minor glomerular abnormalities, whereas electron microscopy depicted numerous abnormal mitochondria in the epithelium of both the glomeruli and the tubules. The authors inferred that mitochondrial damage may be more severe in the jux- 
taglomerular cells than in other kidney cells, leading to hyporeninemic hypoaldosteronism. A similar consideration may be appropriate for our patient.

In summary, the presence of hyperkalemia in patients with MIDD should alert the physician to look for the development of hyporeninemic hypoaldosteronism.

Disclosure: no potential conflict of interest relevant to this article was reported.

\section{REFERENCES}

1. Murphy R, Turnbull DM, Walker M, Hattersley AT. Clinical features, diagnosis and management of maternally inherited diabetes and deafness (MIDD) associated with the 3243A > G mitochondrial point mutation. Diabc Med. 2007;25:383-99.

2. Guillausseau PJ, Massin P, Dubois-LaForgue D, Timsit J, Virally M, $\mathrm{Gin} \mathrm{H}$, et al. Maternally inherited diabetes and deafness: a multicenter study. Ann Intern Med. 2001;134(9):721-8.

3. Maassen JA, 'T Hart LM, van Essen E, Heine RJ, Nijpels G, Tafrechi RSJ, et al. Mitochondrial diabetes: molecular mechanisms and clinical presentation. Diabetes. 2004;53 Suppl 1:S103-9.

4. Maassen JA. Mitochondrial diabetes: pathophysiology, clinical presentation, and genetic analysis. Am J Med Genet. 2002;115:66-70.

5. Katagiri $H$, Asano T, Ishihara $H$, Inukai $K$, Anai M, Yamanouchi T, et al. Mitochondrial diabetes mellitus: prevalence and clinical characterization of diabetes due to mitochondrial tRNA(Leu(UUR)) gene mutation in Japanese patients. Diabetologia. 1994;37(5):504-10.

6. Velho G, Byrne MM, Clément C, Sturis J, Pueyo ME, Blanché $H$, et al. Clinical phenotypes, insulin secretion, and insulin sensitivity in kindreds with maternally inherited diabetes and deafness due to mitochondrial tRNALeu (UUR) gene mutation. Diabetes. 1996;45(4):478-87.

7. Salles JE, Kasamatsu TS, Dib SA, Moisés RS. B-cell function in individuals carrying the mitochondrial tRNA Leu (UUR) mutation. Pancreas. 2007;34(1):133-7.

8. Kobayashi T, Nakanishi K, Nakase H, Kajio H, Okubo M, Murase $\mathrm{T}$, et al. In situ characterization of islets in diabetes with a mitochondrial DNA mutation at nucleotide position 3243. Diabetes. 1997;46(10):1567-71.

9. Lynn S, Borthwick GM, Charnley RM, Walker M, Turnbull DM. Heteroplasmic ratio of the $\mathrm{A} 3243 \mathrm{G}$ mitochondrial DNA mutation in single pancreatic beta cells. Diabetologia. 2003;46:296-9.

10. Yoneda M, Chomyn A, Martinuzzi A, Hurko O, Attardi G. Marked replicative advantage of human mtDNA carrying a point mutation that causes the MELAS encephalomyopathy. Proc Natl Acad Sci U S A. 1992;89(23):11164-8.

11. Massin $P$, Virally-Monod $M$, Vialettes $B$, Paques $M$, Gin $H$. Prevalence of macular pattern dystrophy in maternally inherited diabetes and deafness. GEDIAM Group. Ophtalmology. 1999;106(9):1821-7.

12. Majamaa-Voltti K, Peuhkurinen KJ, Kortelainen M, Hassinen IE, Majamaa K. Cardiac abnormalities in patients with mitochon- drial DNA mutation 3243 A>G. BMC Cardiovascular Disorders. 2002;2:12.

13. Salles JE, Moises VA, Almeida DR, Chacra AR, Moisés RS. Myocardial dysfunction in mitochondrial diabetes treated with Coenzyme 010. Diabetes Res Clin Pract. 2006;72:100-3.

14. Yoshida $R$, Ishida $Y$, Hozumi $T$, Ueno $H$, Kishimoto $M$, Kasuga $M$, et al. Congestive heart failure in mitochondrial diabetes mellitus. Lancet. 1994;344:1375.

15. Matsuzaki M, Izumi T, Shishikura K, Suzuki H, Hirayama Y. Hypothalamic growth hormone deficiency and supplementary $\mathrm{GH}$ therapy in two patients with mitochondrial myopathy, encephalopathy, lactic acidosis and stroke-like episodes. Neuropaediatrics. 2002;33:271-3.

16. SuzukiY, Kadowaki H, AtsumiY, Hosokawa K, Katagiri H, Kadowa$\mathrm{ki}$, et al. A case of diabetic amyotrophy associated with 3243 mitochondrial tRNA(leu; UUR) mutation and successful therapy with Coenzyme Q10. Endocrine J. 1995;42(2):141-5.

17. Suzuki $S$, Hinokio $Y$, Ohtomo $M$, Hirai $M$, Hirai $A, C h i b a ~ M$, et al. The effects of coenzyme $\mathbf{Q 1 0}$ treatment on maternally inherited diabetes mellitus and deafness, and mitochondrial DNA 3243 (A to G) mutation. Diabetologia. 1998;41(5):584-8.

18. SuzukiY,Taniyama M, MuramatsuT, AtsumiY, Hosokawa K, Asahina T, et al. Diabetes mellitus associated with mitochondrial tRNA Leu (UUR) mutation: clinical features and coenzyme Q10 treatment. Mol Aspects Med. 1997;18 Suppl 1:S181-8.

19. Bergamin CS, Rolim LC, Dib SA, Moisés RS. Unusual occurrence of intestinal pseudo obstruction in a patient with maternally inherited diabetes and defness and favorable outcome with Coenzyme 0 10. Arq Bras Endocrinol Metab. 2008;52:1345-9.

20. Chomyn A, Martinuzzi A, Yoneda M, Daga A, Hurko O, Johns D, et al. MELAS mutation in mtDNA binding site for transcription termination factor causes defects in protein synthesis and in respiration but no change in levels of upstream and downstream mature transcripts. Proc Natl Acad Sci USA. 1992;89:4221-5.

21. Hall AM, Unwin RJ, Hanna MG, Duchen MR. Renal function and mitochondrial cytopathy (MC): more questions than answers? 0 J Med. 2008;101:755-66.

22. Jarman PR, Mather HM. Diabetes may be independent risk factor for hyperkalaemia. BMJ. 2003;327(7418):812.

23. De Fronzo RA. Hyperkalemia and hyporeninemic hypoaldosteronism. Kidney Int. 1980;17:118-34.

24. Du BoseTD Jr, Caflish CR. Effect of selective aldosterone deficiency and acidification in nefron segments of the rat inner medulla. $J$ Clin Invest. 1988;82:1624-32.

25. Large DM, Laing I, Carr PH, Davies M. Hyperkalaemia in diabetes mellitus - potential hazards of coexisting hyporeninaemic hypoaldosteronism. Postgrad Med J. 1984;60:370-3.

26. Schindler AM, Sommers SC. Diabetic sclerosis of the renal juxtaglomerular apparatus. Lab Invest. 1966;15:877-84.

27. Misbin RI, Grant MB. Elevated levels of plasma prorenin (inactive renin) in diabetic and nondiabetic patients with autonomic dysfunction. J Clin Endocrinol Metab. 1987;64:964-8.

28. Goldfarb S, Cox M, Singer I, Goldberg M. Acute hyperkalemia induced hyperglycemia: hormonal mechanism. Ann Intern Med. 1976;84:426-32.

29. Shimizu J, Inatsu A, Oshima S, Shimizu E, Hirata H, Yasuda H, et al. Hyperkalaemia in familial mitochondrial cytopathy. Clinical Nephrology. 2008;70(4):348-53. 